\title{
FTO gene variant and association with overweight in Brazilian male students
}

\section{Variante do gene FTO e associação com excesso de peso em estudantes brasileiros do sexo masculino}

\author{
José Fernando Vila Nova de Moraes ${ }^{1,2}$ \\ Orlando Laitano 2 \\ Marcelo Magalhães Sales ${ }^{1}$ \\ Ricardo Yukio Asano \\ Vinícius Carolino de Souza ${ }^{3}$ \\ Otávio de Toledo Nóbrega ${ }^{3}$ \\ Carmen Sílvia Grubert Campbell ${ }^{1}$
}

Abstract - Obesity is considered a disease with multiple etiologies. Recent advances in technology have pointed candidate genes that are related to weight gain in several populations. However, in countries with ethnic miscegenation, such as Brazil, studies of this nature with students are still scarce. The aim of the present study was to compare anthropometric variables of Brazilian male students according to the genotypes of the rs9939609 of the FTO gene. In order to do so, 205 participants underwent body mass, height, waist circumference and skinfold thickness measurements. Body mass index (BMI), waist-to-height ratio and body fat percentage were calculated. Volunteers were characterized as overweight according to the BMI-for-age z-score. Participants were genotyped according to the single nucleotide polymorphism rs9939609 of the FTO gene (AA, AT and TT). ANOVA one-way with Bonferroni's post hoc was performed to compare genotypes and anthropometric variables. Odds Ratio was calculated to reveal increased chances of presenting higher body mass index $z$-score, waist-to-height ratio and body fat percentage. Participants homozygous for the A allele presented significantly higher values of BMI-for-age $\mathrm{z}$-score $(0.38 \pm 1.01$ vs. $-0.29 \pm 1.15)$, waist circumference $(77.15 \pm 6.51$ vs. $72.85 \pm 7.36 \mathrm{~cm})$ and waist-to-height ratio $(0.44 \pm 0.04$ vs. $0.42 \pm 0.04)$ when compared to individuals with the TT genotype. The A allele of the rs 9939609 of the FTO gene seems to influence in the adiposity of male students.

Key words: Anthropometry; Genetics; Overweight; Single nucleotide polymorphism; Students.

Resumo - A obesidade é considerada doença com múltipla etiologia. Avanços recentes na tecnologia têm apontado genes candidatos que estão relacionados ao ganho de massa corporal em diversas populações. Entretanto, em países com miscigenação étnica, como o Brasil, estudos dessa natureza com escolares ainda são escassos. Objetivou-se comparar variáveis antropométricas em estudantes brasileiros do sexo masculino de acordo com os genótipos do rs 9939609 do gene FTO. Para tanto, 205 participantes tiveram sua massa corporal, estatura, circunferência da cintura e dobras cutâneas medidos. Indice de massa corporal (IMC), relação cintura-estatura epercentual de gordura foram calculados. Os voluntários foram classificados como com excesso de peso de acordo com o escore-z de IMC por idade. Ademais, os participantes foram genotipados conforme o polimorfismo de nucleotídeo único rs9939609 do gene FTO (AA, AT e TT). ANOVA de uma entrada com post hoc de Bonferroni foi realizada para comparar as variáveis antropométricas entre os genótipos. Odds ratio foi calculada no intuito de revelar chances aumentadas de apresentar maior escore-z de IMC por idade, razão cintura-estatura e percentual de gordura. Os individuos homozigotos para o alelo A apresentaram valores significativamente mais altos para escore-z de $I M C$ por idade $(0,38 \pm 1,01$ vs. $-0,29 \pm 1,15)$, circunferência da cintura $(77,15 \pm 6,51$ vs. $72,85 \pm 7,36 \mathrm{~cm})$ e relação cintura-estatura $(0,44 \pm 0,04$ vs. 0,42 $\pm 0,04)$ quando comparados aos indivíduos com genótipo TT. O alelo A do rs9939609 do gene FTO parece influenciar a adiposidade de estudantes do sexo masculino.

Palavras-chave: Antropometria; Estudantes; Genética; Polimorfismo de nucleotídeo único; Sobrepeso.
1 Catholic University of Brasília. Graduate Program in Physical Education. Brasília, DF. Brazil.

2 Federal University of Vale do São Francisco. College of Physical Education. Petrolina, PE. Brazil.

3 University of Brasília. Graduate Program in Medical Sciences. Brasília, DF. Brazil.

Received: 18 August 2015 Accepted: 22 April 2016 


\section{INTRODUCTION}

Obesity is considered a disease with multiple etiologies. It is usually a result of an unbalance between caloric intake and expenditure. However, its origins can be determined by factors related to metabolism, environment (eating habits and physical activity), psychological disorders and genetics ${ }^{1}$.

The influence of genetics on excessive weight became more frequent in literature after the study published by Frayling et al. ${ }^{2}$ They performed an association between 490,000 single nucleotide polymorphisms (SNPs) and the presence of type II diabetes in English adults. The results showed that the SNP rs9939609, of the FTO gene (Fat mass and obesity associated), situated on chromosome 16, was strongly associated to type II diabetes and increased body mass index (BMI). However, after statistical adjustments for BMI, the association between the SNP rs9939609 and type II diabetes lost its significance. Therefore, the authors concluded that the presence of diabetes in this population was due to elevated BMI values.

Afterwards, studies with SNPs from the FTO gene, especially the rs9939609, started to gain attention of researchers. In Chinese adults, Li et al. ${ }^{3}$ observed that individual homozygous to the A allele presented significantly higher chances of being obese and developing type II diabetes. Legry et al. ${ }^{4}$ referred an increased risk of $20.9 \%$ of being obese in French adults that carried the A allele when compared to individuals with the TT genotype.

In children and adolescents, literature also states that the $\mathrm{A}$ allele carriers of the rs9939609 of the FTO gene present increased chances of excessive weight. Dušátková et al. ${ }^{5}$, studying 1443 adolescents aged $13-17.9$ years from the Czech Republic, reported an increase of $40.0 \%$ of obesity in subjects that carried the A allele. In addition, Ruiz et al. ${ }^{6}$, studying 752 adolescents, referred that the presence of the A allele was significantly associated with higher BMI, body fat percentage and waist circumference.

However, in countries with ethnic miscegenation, such as Brazil, studies of this nature with students are still scarce. Brazil's Northeastern region, in particular, has a mixed gene pool that is originated from Native Amerindians, Africans and Europeans. As of today, only eight studies involving the interaction of FTO and body adiposity using Brazilian populations have been published ${ }^{7-12}$. Only two of these studies involve children and adolescents ${ }^{13,14}$.

In this scenario, the aim of the present study was to verify differences in anthropometric variables of Brazilian male students according to the different genotypes of the SNP rs9939609 of the FTO gene.

\section{METHODOLOGICAL PROCEDURES}

\section{Sample and ethical procedures}

Three high schools from the city of Petrolina, state of Pernambuco, Brazil, were randomly selected and all male students enrolled in the schools were invited to participate in the study. Only the ones who returned the 
informed consent term signed by a parent (or himself if aged 18 or more) participated in the study. In total, 205 students, aged 14 to 20 years, participated (26.62\%).

The present study was approved by the Ethics Committee of the Catholic University of Brasília (protocol number 195/2010) and all procedures were in accordance with the Declaration of Helsinki and the Resolution 466/2012 of the Brazilian National Health Council.

\section{Sexual maturation}

Initially, all participants informed their name, date of birth and age. Afterwards, sexual maturation was self-evaluated using Tanner's charts ${ }^{15}$. In order to do so, the participant was asked to look at drawings of the male reproductive organ and to indicate which picture better represented the stage they were in (stages 1 to 5).

\section{Anthropometric evaluation}

Anthropometric evaluation was performed by measurements of body mass, height, BMI, waist circumference, waist-to-height ratio and body fat percentage.

Body mass was measured with a digital scale (Wiso ${ }^{\circledR}$, Brazil) and height was assessed with a portable stadiometer (Wiso ${ }^{\circledR}$, Brazil). During both measurements the participants were without shoes and wore light clothes. BMI was calculated dividing body mass $(\mathrm{kg})$ by the squared value of height $\left(\mathrm{m}^{2}\right)$. Overweight and obesity were characterized using the BMI-for-age $z$-scores defined by the World Health Organization ${ }^{16}$. Values between +1.00 and +1.99 were considered overweight and values higher than +2.00 were considered obese. Subjects aged 18 or older were characterized according to BMI values for adults (overweight between 25.00 and $29.99 \mathrm{~kg} / \mathrm{m}^{2}$ and obese above $\left.30.00 \mathrm{~kg} / \mathrm{m}^{2}\right)^{17}$. Overweight and obese participants were grouped in the statistical analysis.

Waist circumference was measured with a non-extendible tape (CESCORF ${ }^{\circledR}$, Brazil). The measurement was made between the last rib and the iliac crest. Values were considered high when equal or above the $90^{\text {th }}$ percentile for age, according to Fernández et al. ${ }^{18}$. Waist-to-height ratio was calculated by dividing waist circumference $(\mathrm{cm})$ by height $(\mathrm{cm})$ and values were considered high when equal or above $0.50^{19}$.

Triceps and calf skinfolds were measured according to Heyward and Stolarczyk ${ }^{20}$ and body fat percentage was calculated using the equation created by Slaughter et al. ${ }^{21}$ Values equal or higher than $20 \%$ were considered high.

\section{DNA extraction and genotyping of the rs9939609}

Blood samples were obtained from the antecubital vein by a trained professional. Three to five $\mathrm{ml}$ of blood was drawn in tubes containing EDTA anti-coagulant. DNA was obtained from peripheral blood leukocytes by using a DNA extraction kit according to the manufacturer's 
recommendations (QIAamp DNA Blood Kits - QIAGEN, Germany)22. The extracted DNA was stored at $-80^{\circ} \mathrm{C}$ for subsequent analysis.

The polymorphism in the human FTO gene (rs9939609) was determined by direct sequencing of a $182 \mathrm{bp}$ Polimerase Chain Reaction (PCR) product amplified using a pair of specific primers: 5' - AACTGGCTCTTGAATGAAATAGGATTCAGA - 3' (sense) and 5' - AGAGTAACAGAGACTATCCAAGTGCAGTAC - 3' (antisense). Reaction tubes contained $100 \mathrm{ng}$ DNA, $10 \mathrm{mmol} / 1$ Tris $-\mathrm{HCl} \mathrm{pH}$ 8.3, $75 \mathrm{mmol} / \mathrm{KCl}$, $3.5 \mathrm{mmol} / 1 \mathrm{MgCl} 2,0.2 \mathrm{mmol} / 1 \mathrm{dNTP}, 20 \mathrm{pmol}$ of each primer, $0.5 \mu \mathrm{g}$ of ovalbumin and $1 \mathrm{U}$ of Taq DNA polymerase (Invitrogen, Brazil) in a final volume of $25 \mu \mathrm{l}$. After $1 \mathrm{~min}$ of hot start at $80^{\circ} \mathrm{C}$ and an initial denaturation for $5 \mathrm{~min}$ at $94^{\circ} \mathrm{C}$, the amplifications were performed using 35 cycles of $45 \mathrm{~s}$ at $94{ }^{\circ} \mathrm{C}, 45 \mathrm{~s}$ at $62{ }^{\circ} \mathrm{C}$ and $45 \mathrm{~s}$ at $72{ }^{\circ} \mathrm{C}$ followed by a final $10 \mathrm{~min}$ extension at $72{ }^{\circ} \mathrm{C}$. Each PCR product was directly sequenced on a ABI PRISM 3700 DNA analyzer (Applied Biosystems ${ }^{\circledR}$, USA), using the sense primer. Each sequence obtained was examined using the Staden software package (MRC ${ }^{\circledR}$, United Kingdom), and confirmed by visual inspection.

\section{Statistical Analysis}

A descriptive analysis of the data was performed and values are expressed in relative frequency (\%) and mean \pm standard-deviation. The correction of the outliers was performed adding one unit to the extreme value ${ }^{23}$. ChiSquare test was performed to verify the balance between the genotypes of the rs9939609 of the FTO genes ${ }^{24}$. Statistical power a priori for the Chi-Square test was 93.3\% (Power=0.933), considering and effect size of $\mathrm{w}=0.3$ and an alpha of $5.0 \%$.

A One-Way Analysis of Variance (ANOVA) with Bonferroni's post hoc was performed to verify the differences between the genotypes and the anthropometric variables. For this test the statistical power a priori was 90\% (Power $=0.90$ ) considering an effect size of $\mathrm{f}=0.25$, three groups (AA, AT and TT) and an alpha of 5.0\%.

Finally, odds ratio was calculated using the Crosstabs option (confidence interval of 95\%), with the aim of verifying if the individuals carrying the A allele had higher chances of presenting increased BMI-for-age z-score, waist circumference and waist-to-height ratio.

The level of significance adopted was 5.0\% ( $p<0.05)$. Power was calculated using $G^{*}$ Power and statistical procedures were performed on the o Statistical Package for the Social Sciences (SPSS), version 15.0 for Windows ${ }^{\circledR}$.

\section{RESULTS}

The main characteristics of the participants are shown in table 1 . Of the 205 volunteers, 35 (17.1\%) presented excessive weight according to their BMI-for-age z-score, 31 (15.1\%) showed high body fat percentage values, 14 (6.8\%) had increased waist-to-height ratio and only two (1.0\%) volunteers presented elevated waist circumference. 
Table 1. Sample's main characteristics $(n=205)$.

\begin{tabular}{lc}
\hline Variables & Mean \pm standard deviation \\
\hline Age (years) & $16.25 \pm 1.27$ \\
Tanner's maturational stage & $4.20 \pm 0.63$ \\
Body mass $(\mathrm{kg})$ & $64.45 \pm 12.34$ \\
Height $(\mathrm{cm})$ & $173.47 \pm 6.62$ \\
Body mass index $\left(\mathrm{kg} / \mathrm{m}^{2}\right)$ & $21.34 \pm 3.52$ \\
BMl-for-age z-score & $-0.04 \pm 1.19$ \\
Waist circumference $(\mathrm{cm})$ & $74.22 \pm 7.51$ \\
Waist-to-height ratio & $0.43 \pm 0.04$ \\
Triceps skinfold (mm) & $8.89 \pm 3.32$ \\
Calf skinfold $(\mathrm{mm})$ & $9.96 \pm 4.01$ \\
Sum of skinfolds $(\mathrm{mm})$ & $18.85 \pm 7.11$ \\
Body fat $(\%)$ & $14.88 \pm 5.27$ \\
\hline
\end{tabular}

$\mathrm{BMI}=$ body mass index.

Among the participants, 27 (13.2\%) presented the AA genotype, 103 (50.2\%) were heterozygous (AT) and 75 (36.6\%) were TT allele carriers. Hardy-Weinberg's test revealed equilibrium between genotypes $\left(\mathrm{X}^{2}=0.82\right.$; $\mathrm{p}=0.36$ ). The comparison between the anthropometric variables and the different genotypes of the rs 9939609 of the FTO gene are shown in table 2. Participants homozygous for the A allele presented significantly higher values of BMI-for-age $\mathrm{z}$-score, waist circumference and waist-to-height ratio when compared to TT allele carriers.

Table 2. Anthropometric variables according to the genotypes of the rs9939609 of the FTO gene $(n=205)$. Values shown in mean \pm standard deviation.

\begin{tabular}{lccc}
\hline Variables & AA $(\mathrm{n}=27)$ & AT $(\mathrm{n}=103)$ & TT $(\mathrm{n}=75)$ \\
\hline \multicolumn{3}{c}{ Mean \pm standard deviation } \\
\hline Body mass $(\mathrm{kg})$ & $68.02 \pm 10.14$ & $65.53 \pm 12.98$ & $61.69 \pm 11.74$ \\
Height $(\mathrm{cm})$ & $174.41 \pm 7.16$ & $173.69 \pm 6.60$ & $172.83 \pm 6.48$ \\
BMI $\left(\mathrm{kg} / \mathrm{m}^{2}\right)$ & $22.31 \pm 2.77$ & $21.64 \pm 3.73$ & $20.57 \pm 3.34$ \\
BMI-for-age z-score & $0.38 \pm 1.01^{*}$ & $0.04 \pm 1.22$ & $-0.29 \pm 1.15$ \\
Waist circumference $(\mathrm{cm})$ & $77.15 \pm 6.51^{*}$ & $74.45 \pm 7.69$ & $72.85 \pm 7.36$ \\
Waist-to-height ratio & $0.44 \pm 0.04^{*}$ & $0.43 \pm 0.04$ & $0.42 \pm 0.04$ \\
Triceps skinfold $(\mathrm{mm})$ & $9.56 \pm 3.46$ & $9.03 \pm 3.40$ & $8.45 \pm 3.14$ \\
Calf skinfold $(\mathrm{mm})$ & $11.00 \pm 4.69$ & $10.13 \pm 3.88$ & $9.34 \pm 4.02$ \\
Sum of skinfolds $(\mathrm{mm})$ & $20.55 \pm 7.71$ & $19.15 \pm 7.03$ & $17.81 \pm 6.95$ \\
Body fat $(\%)$ & $16.14 \pm 5.72$ & $15.11 \pm 5.21$ & $14.10 \pm 5.12$ \\
\hline
\end{tabular}

$\mathrm{BMI}=$ body mass index. ${ }^{*} \mathrm{p} \leq 0.05$ to TT genotype.

Odds ratio revealed that carriers of the A allele of the rs9939609 of the FTO gene presented 1.83 more chances of having an increased BMI-for-age $z$-score when compared with individuals homozygous for the $\mathrm{T}$ allele. These chances were 1.48 and 1.49 times higher regarding waist-to-height ratio and body fat percentage, respectively. However, these increased chances did not reach statistical significance $\left(\mathrm{X}^{2}=2.15\right.$ for BMI-for-age $z$-score; $X^{2}=0.52$ for waist-to-height ratio; and $X^{2}=0.90$ for body fat percentage; $p>0.05$ ), as shown in table 3 . 
Table 3. Odds ratio for increased BMI-for-age z-score, body fat percentage and waist-to-height ratio according to the genotypes of the rs9939609 of the FTO gene $(n=205)$.

\begin{tabular}{lccc}
\hline $\mathrm{n}$ & \multicolumn{3}{c}{ Increased BMI-for-age z-score } \\
\hline 75 & TT & Odds ratio & $\mathrm{Cl}(95 \%)$ \\
\hline 130 & AA/AT & 1.83 & - \\
\hline $\mathrm{n}$ & & Increased body fat percentage \\
\hline \multicolumn{5}{c}{ Odds ratio } & $\mathrm{Cl}(95 \%)$ \\
\hline 75 & TT & 1 & - \\
130 & AA/AT & 1.49 & $0.65-3.44$ \\
\hline $\mathrm{n}$ & & Increased waist-to-height ratio & \\
\hline \multicolumn{5}{c}{} & Odds ratio & $\mathrm{Cl}(95 \%)$ \\
\hline 75 & TT & 1 & - \\
130 & AA/AT & 1.48 & $0.45-4.89$ \\
\hline
\end{tabular}

$\mathrm{Cl}=$ confidence interval.

\section{DISCUSSION}

In the present study, participants homozygous for the A allele of the rs9939609 of the gene FTO presented significantly higher values of BMI-for-age $\mathrm{z}$-score, waist circumference and waist-to-height ratio when compared to those homozygous for the $\mathrm{T}$ allele. In addition, odds ratio showed that participants carrying the A allele presented more chances, although not statistically significant, of having increased values of BMIfor-age $\mathrm{z}$-score, waist-to-height ratio and body fat percentage $(83.0 \%$, $48.0 \%$ and $49.0 \%$, respectively).

Several studies have associated the presence of the A allele of the rs9939609 of the FTO gene with increased body adiposity. In the original study that first showed this association, Frayling et al. ${ }^{2}$ observed that adults homozygous for the A allele presented higher body mass (3.0 kilos) and $67.0 \%$ more chances of being obese.

In children and adolescents, Ruiz et al. ${ }^{6}$ reported higher BMI, body fat percentage and waist circumference in A allele carriers. Moreover, Dušátková et $a 1 .{ }^{5}$, in a similar design, reported $40.0 \%$ more chances of developing obesity in adolescents from the Czech Republic.

On the other hand, Bollepalli et al. ${ }^{25}$ found no associations between the polymorphisms of the rs 9939609 of the FTO gene and adiposity in AfricanAmerican students aged 10-18 years. According to the authors, ethnic distinctions in metabolic risks factors could explain theses differences, since they found lower amounts of visceral fat in African-Americans when compared to non-Hispanic white students.

In Brazil, only two studies involving associations between the polymorphisms of the rs9939609 of the FTO gene and anthropometric profile in children and adolescents have been published. Lourenço et al. ${ }^{14}$, in a longitudinal study with a mean duration of 4.6 years, evaluated 1,225 children with less than 10 years of age in the city of Acrelândia, situated in the Brazilian Amazon Rainforest region. The authors observed that the presence of the A allele was associated with an increase in BMI of $0.57 \mathrm{~kg} /$ 
$\mathrm{m}^{2}$ and a BMI-for-age $\mathrm{z}$-score 0.25 unit higher when compared to children homozygous for the $\mathrm{T}$ allele.

Likewise, Silva et al. ${ }^{13}$, following 348 children since birth until the age of 8 , reported significantly higher values of BMI-for-age $\mathrm{z}$-score, starting at the age of 4 in participants with the AA genotype. These differences were maintained until the age of 8 . Moreover, the authors replicated these findings in 615 students aged $4-18$ years and found significant differences in BMI-for-age $z$-score and subcutaneous fat in the participants that carried the A allele.

Although these above mentioned studies bring important information about the associations between the variants of the FTO gene and adiposity in Brazilian students, the present study innovates since it is the first to approach a more ethnically mixed population, such as the Brazilian Northeastern semi-arid region ${ }^{26}$.

The mechanisms that explain why the polymorphisms of the rs9939609 of the FTO gene influence in the accumulation of body adiposity have not yet been elucidated ${ }^{27}$. However, Benedict et al. ${ }^{28}$ found that FTO may facilitate weight gain by increasing grelin (hunger hormone) and decreasing leptine (saciety hormone) plasma levels. Finally, Almén et al. ${ }^{29}$, on the other hand, suggested that the FTO gene could possibly influence in the methylation of other genes. According to the authors, one of these genes could be the TERF2IP, which is associated to the body's response to inflammatory processes. Finally, Merkestein et al. ${ }^{30}$ described that FTO may influence weight gain by regulating adiponegenesis.

Even though the findings of the present study are important, they should be analyzed with caution. First, although the results showed statistically significant differences between the different genotypes of the rs9939609 of the FTO gene in Brazilian male students, it is not possible to describe the mechanisms that underlie these findings. Moreover, aspects regarding eating habits and exercise must be considered, since they directly influence the variables studied. The lack of control on the period of the day in which the measurements were performed can be considered as a limitation, since height and body mass can slightly change throughout a $24-\mathrm{h}$ period. Lastly, the cross-sectional nature of the study does not allow establishing a cause-effect relationship among the variables studied.

\section{CONCLUSIONS}

The present study showed that the presence of the A allele of the rs9939609 of the FTO gene seems influence in the adiposity of male students, since the participants homozygous for the A allele presented higher values of BMIfor-age $\mathrm{z}$-score, waist circumference and waist-to-height ratio. Moreover, the presence of the A allele reflected in higher, although not significant, chances of presenting increased BMI-for-age $\mathrm{z}$-score, waist-to-height ratio and body fat percentage. 


\section{REFERENCES}

1. Weinsier RL, Hunter GR, Heini AF, Goran MI, Sell SM. The etiology of obesity: relative contribution of metabolic factors, diet, and physical activity. Am J Med 1998;105(2):145-50.

2. Frayling TM, Timpson NJ, Weedon MN, Zeggini E, Freathy RM, Lindgren $\mathrm{CM}$, et al. A common variant in the FTO gene is associated with body mass index and predisposed to childhood and adult obesity. Science 2007;316(5826):889-94.

3. Li X, Song F, Jiang H, Zhang M, Lin J, Bao, W, et al. A genetic variation in the fat mass- and obesity-associated gene is associated with obesity and newly diagnosed type 2 diabetes in a Chinese population. Diabetes Metab Res Rev 2010;26(2):128-32.

4. Legry V, Cottel D, Ferrières J, Arveiler D, Andrieux N, Bingham A, et al. Effect of an FTO polymorphism on fat mass, obesity, and type 2 diabetes mellitus in the French MONICA Study. Metabolism 2009;58(7):971-75.

5. Dušátkova L, Zamrazilová $\mathrm{H}$, Sedláčková $\mathrm{B}$, Včelák J, Hlavatý $\mathrm{P}$, Aldhoon Hainerová I. Association of obesity susceptibility gene variants with metabolic syndrome and related traits in 1,443 Czech adolescents. Foila Biol (Praha) 2013;59(3):123-33.

6. Ruiz JR, Labayen I, Ortega FB, Legry V, Moreno LA, Dallongeville J, et al. Attenuation of the effect of the FTO rs9939609 polymorphism on total and central body fat by physical activity in adolescents. Arch Pediatr Adolesc Med 2010;164(4):328-33.

7. Steemburgo T, Azevedo MJ, Gross JL, Milagro FI, Campión J, Martínez JÁ. The rs9939609 polymorphism in the FTO gene is associated with fat and fiber intakes in patients with type 2 diabetes. J Nutrigenet Nutrigenomics 2013;6(2):97-106.

8. Steemburgo T, Azevedo MJ, Gross JL, Campión J, Martínez JÁ. The rs7204609 polymorphism in the fat mass and obesity-associated gene is positively associated with central obesity and microalbuminuria in patients with type 2 diabetes from southern Brazil. J Ren Nutr 2012;22(2):228-36.

9. Ramos AV, Bastos-Rodrigues L, Resende BA, Friedman E, Campanha-Versiani L, Miranda DM, et al. The contribution of FTO and UCP-1 SNPs to extreme obesity, diabetes and cardiovascular risk in Brazilian individuals. BMC Med Genet 2012;13(1):101-9.

10. Ramos RB, Casanova GK, Maturana MA, Spritzer PM. Variations in the fat mass and obesity-associated (FTO) gene are related to glucose levels and higher lipid accumulation product in postmenopausal women from southern Brazil. Fertil Steril 2011;96(4):974-9.

11. Ramos RB, Casanova GK, Spritzer PM. Fat mass and obesity-associated gene polymorphisms do not affect metabolic response to hormone therapy in healthy postmenopausal women. Eur J Obset Gynecol Reprod Biol. 2012;165(2):302-6.

12. Curti ML, Rogero MM, Baltar VT, Barros CR, Siqueira-Catania A, Ferreira SR. FTO T/A and peroxisome proliferator-activated receptor-y Pro12Ala polymorphisms but not ApoA1 -75 are associated with better response to lifestyle intervention in Brazilians at high cardiometabolic risk. Metab Syndr Relat Disord 2013;11(3):169-76.

13. Silva CF, Zandoná MR, Vitolo MR, Campagnolo PDB, Rotta LNA, Almeida S, et al. Association between a frequent variant of the FTO gene and anthropometric phenotypes in Brazilian children. BMC Med Genet 2013;14(1):34-41.

14. Lourenço BH, Qi L, Willet WC, Cardoso MA, for the action study team. FTO genotype, Vitamin D status and weight gain during childhood. Diabetes 2014;63(2):808-14.

15. Marshall WA, Tanner JM. Variations In the pattern of pubertal changes in boys. Arch Dis Child 1970;45(239):13-23.

16. World Health Organization (WHO). WHO AnthroPlus for personal computers Manual: Software for assessing growth of the world's children and adolescents. Geneva: WHO, 2009. 
17. World Health Organization (WHO). Obesity: preventing and managing the global epidemic: report of a WHO consultation. Geneva: WHO, 2000.

18. Fernández JR, Redden DT, Pietrobelli A, Allison DB. Waist circumference percentiles in nationally representative samples of African-american, Europeanamerican, and Mexican-american children and adolescents. J Pediatr 2004;145(4):439-44.

19. Pitanga JF, Lessa I. Waist-to-height ratio as a coronary risk predictor among adults. Rev Bras Assoc Med 2006;52(3):157-61.

20. Heyward VH, Stolarczyk LM. Applied body composition assessment. São Paulo: Manole, 1996.

21. Slaughter MH, Lohman TG, Boileau RA, Horswill CA, Stillman RJ, Van Loan $\mathrm{MD}$, et al. Skinfold equations for estimation of body fatness in children and youth. Hum Biol 1988;60(5):709-23.

22. QIAGEN. QIAmp ${ }^{\circledR}$ DNA mini and blood mini handbook. Germany: QIAGEN, 2010.

23. Iglewicz B, Hoaglin DC. How to Detect and Handle Outliers (ASQC Basic References in Quality Control). Milwaukee, WI: American Society for Quality Control, 1993.

24. Rodriguez S, Gaunt TR, Day INM. Hardy-Weinberg equilibrium testing of biological ascertainment for mendelian randomization studies. Am J Epidemiol 2009;169(4):505-14.

25. Bollepalli S, Dolan LM, Deka R, Martin LJ. Association of FTO gene variants with adiposity in African-American adolescents. Obesity 2010;18(10):1959-63.

26. IBGE (Instituto Brasileiro de Geografia e Estatística). Síntese de indicadores sociais: uma análise das condições de vida da população brasileira. IBGE, Coordenação de População e Indicadores Sociais. Rio de Janeiro: IBGE, 2015.

27. Lima WA, Glaner MF, Taylor AP. Fenótipo da gordura, fatores associados e o polimorfismo rs9939609 do gene FTO. Rev Bras Cineantropom Desempenho Hum 2010;12(2):164-72.

28. Benedict C, Axelsson T, Söderberg S, Larsson A, Ingelsson E, Lind L, et al.. Fat Mass and Obesity-Associated Gene (FTO) Is Linked to Higher Plasma Levels of the Hunger Hormone Ghrelin and Lower Serum Levels of the Satiety Hormone Leptin in Older Adults. Diabetes 2014;63(11):3955-9.

29. Almén MS, Jacobsson JA, Moschonis G, Benedict C, Chrousos G, Fredriksson $\mathrm{R}$, et al. Genome wide analysis reveals association of a FTO gene variant with epigenetic changes. Genomics 2012;99(3):132-137.

30. Merkestein M, Laber S, McMurray F, Andrew D, Sachse G, Sanderson J, et al. FTO influences adipogenesis by regulating mitotic clonal expansion. Nat Commun 2015;6:6792.

\section{CORRESPONDING AUTHOR}

José Fernando Vila Nova de Moraes Av. José de Sá Maniçoba, s/n, Centro

Petrolina - PE, Brazil.

Zip Code: 56204-305

E-mail: josefernando.moraes@

univasf.edu.br 